\title{
Geographical Imaginations of the Mediterranean Along Dichotomies of East-West/North-South
}

\author{
Doğu-Batı/Kuzey-Güney İkilikleri Çerçevesinde Coğrafi Bir Tahayyül \\ Olarak Akdeniz ${ }^{*}$
}

\author{
Sezgi DURGUN**
}

\begin{abstract}
This article endeavours to analyse the European and Turkish discourses regarding the concept of the "Mediterranean" and its variations both in temporal and spatial terms. The theoretical inspiration of this article comes from the "geographical imagination as a way of thinking about world politics and considering the relative importance of places and the relationships between contested narratives of a specific region or territory". Hence this study will examine different geographical imaginations of the Mediterranean region that are projected onto both Turkish and European political discourse. The perspective which is engaged here involves the historical geography, or geosophy put forward by J. K. Wright (1946) who assumed that geographical knowledge is not only a knowledge of physical characteristics and natural resources, but is also something being defined and redefined by the political imagination of the perceiver. So in this article a "geosophical" perspective will be applied to the Mediterranean region that plays both a historical and strategic role in Euro-Turkish relations.

Keywords: Mediterranean, Geosophy, Geographical Imagination, East-West/North South Dichotomy, Political Geography

Öz

Bu makalede Avrupa Birliği ve Türkiye’nin siyasal söyleminde "Akdeniz" kavramı mekânsal ve tarihsel boyutlarıyla ele alınıyor. Makalenin teorik zemini dünya siyasetinde coğrafi imgelemin oynadığı rollerden ilham alıyor. Bir tahayyül olarak coğrafi anlatılar zaman zaman örtüşen zaman zaman çatışan eksenlerde karşımıza çıkabiliyor; makalede Akdeniz örneğine bakarak Avrupa ve Türk söyleminin bu bölgeyi nasıl tahayyül ettiği tarihsel ve siyasal anlatıların nerelerde çakışıp nerelerde birbirinden ayrıldığı konu edilmekte. Konuya yaklaşım şekli J.K Wright' in “jeozofi” olarak adlandırabileceğimiz perspektifinden güç alıyor. Jeozofik yaklaşım sayesinde coğrafi epistemolojinin sadece fiziksel ve doğal kaynaklardan ibaret olmadığı, insan tahayyülünün de coğrafi bilginin şekillendirici bir parçası olduğu tartışılıyor. Böylelikle AB - Türkiye ilişkilerinde önemli rol oynayan "Akdeniz" anlatısı ve bu bölgeye dair stratejiler iki farklı açıdan tartışmaya açılıyor.
\end{abstract}

* Bu makale Marmara BAPKO projesi kapsamında SOS-D-1502180080 numaralı D tipi proje desteği ile hazırlanmıştır.

* Dr, Department of Political Science and International Relations, Marmara University, sezgi2005@gmail.com. 
Anahtar Kelimeler: Akdeniz, Jeozofi, Coğrafi Tahayyül, Doğu-Batı/Kuzey Güney İkiliği,Siyasi Coğrafya

The most fascinating terrae incognitae of all are those that lie within the hearts and minds of men.

J.K. Wright (1946, AAG conference presidential address, USA)

\section{Introduction}

When the above-mentioned notion "terrae incognitae in the hearts and minds of men" was expressed (Wright 1947, p. 37/1-15), there was not even a trace of Edward Said's "imaginative geographies", or Benedict Anderson's “imagined communities". For these terms to come forward we had to wait for historical processes and new theoretical paradigms such as critical geopolitics ${ }^{1}$ that would make room for deconstructing various types of political identifications, nationalisms, and colonization. In particular, when "world maps" started to be seen from a critical viewpoint (Harley 1988, p. 289-290), doubts were cast on images of the world that were once taken for granted. Hence these processes invite us to think more critically about the relationship between geography and politics.

One may assume that what might have inspired J. K Wright's idea of "terrae incognitae" was his reflection on how powerful human imagination would be in shaping the external reality. We may also assume here that the philosophical background of this argument may stems from Immanuel Kant, who was lecturing on geography besides philosophy at the University of Königsberg. Among the philosophers, Kant stands out not only for initiating the tradition of the Enlightenment, but also as a pioneer in synthesizing the anthropological perspective with the discipline of geography. His most powerful argument is that the perceiving mind has an imprint on the thing perceived. According to him, the knowledge of the world or cosmology (Welterkenntniss) is a combination of physical geography (object of external sense) and anthropology (as an object of inner sense) (Kant 1801).

We may argue that J. K. Wright is one of the outstanding geographers who follows a Kantian line of thought and combines philosophical thinking with geography as giving birth to "geosophy" (in his terminology). He gives the early hints of critical geography since he is well aware of the potential constructive nature of geographical imagination and the political role of the thinker. Hence Wright's "argument of terrae incognitae" marks the premature predictions that political geography would play a transformative role in the future of the social sciences.

Hence from the 1970's on, the discipline of geography became more included in interdisciplinary studies (local governments, urban sociology, spatial politics, international migration, glocalism, etc.) Hence, in recent studies space is no longer perceived as a passive physical background in politics, but becomes an active variable that brought about the discussion over the relation

1 Critical geopolitics is a platform that emerged in the 1990s at the interface between Political Geography and International Relations. See Agnew, J. (1998); Tuathail, G. (1996); Ó Tuathail, G. et al. (2006). 
between the perceiver and the perceived space. Since the 1980s, discussions over "space-place" have gained ground. In this context, space is not seen as a naturally given condition but a vibrant phenomenon that is rooted in long durée human experience. This perspective plays an important role in the constructivist's analysis of nation building as well as "boundary/identity" studies. Hence from the 1970s onwards there has been a growing interest in critical studies regarding space and world politics. Within this context geographical imagination is often used as a term to embrace a variety of meanings, including individual mental images and socially produced discourses on cultures, spaces, and differences. There is also a growing academic interest in critical geopolitics that questions long-standing "geopolitical dogmas" in Turkey ${ }^{2}$.

Geographical imagination assumes that how people see the world is influenced by many factors, including social class, education, and personal and political philosophies. Even the particular moments in history in which people live also play a major role in how they view the world around them ${ }^{3}$. As Massey (2006) argues:

"We carry around with us mental images of the world, of the country in which we live (all those images of the North/South divide), of the street next door. [ ...]All of us carry such images, they may sometimes be in conflict or even be the cause of conflict, and digging these things up and talking about them is one good way to begin to examine what it means to think geographically".

Moreover, Derek Gregory (1994) explains that the "geographical imagination" has a significant role in shaping much of the world's social and spatial thought. Through the geographical imagination, people (both individually and collectively) develop a sense of boundaries, which separate "our territory" from theirs.

Turning back to Wright, what he meant by historical thinking on geography (or "geosophy" in his terms) is the "subject is usually understood to deal with the record of geographical knowledge as acquired through exploration and field work, and as formalized and made into a discipline, and most of the work that has actually been done in the field has been restricted to the core area of geographical knowledge to the exclusion of its peripheral zone.” As Wright (1947) adds more to it:

"...Through the ages men have been drawn to unknown regions by Siren voices, echoes of which ring in our ears today when on modern maps we see spaces labelled "unexplored," rivers shown by broken lines, islands marked "existence doubtful." In this address I shall deal with terrae incognitae, both literal and as symbolizing all that is geographically

2 See Bilgin, P. (2012); For a critical study in the Turkish literature see Türkiye Dünyanın Neresinde? (Eds.) Bilgin P, Durgun S. \& Yeşiltaş M. (2015).

3 In the 1990s "space and place" gained popularity; especially in postmodern studies which took it as a socio-political problematic. This perspective deeply influenced present-day urban theory and human geography, as seen in the work of authors such as David Harvey (1996) and Edward Soja (1989), and in contemporary discussions around the notion of spatial justice. 
unknown; I shall discuss the appeal that they make to the imaginative faculties of geographers and others and the place of the imagination in geographical studies[...]

There is merit in conceiving it more comprehensively. I have already suggested that geographical knowledge of one kind or another is universal among men, and in no sense a monopoly of geographers. All persons know some geography, and I venture to think that many of the animals do, also.

According to the humanist school in geography, space-place is conceptualized as a "life-world". French sociologist Henri Lefebvre and the Neo-Marxist tradition argue that there are different modes of production of space (i.e. spatialization) from natural space (absolute space) to more complex spatialities whose significance is socially produced (i.e. social space). Upon this ground, in reference to the famous argument, "there is a politics of space because space is political" (Lefebvre 1974) we can argue that every perspective involves a political projection.

In support of the idea that geographical imagination is one of most important political tools, Fotiadis (2008/2009) argues different orientations provide different views of the world, and are often chosen specifically to make the viewer adopt the same viewpoint as the mapmaker. There is nothing natural about a particular orientation; it is the dominance of socially constructed beliefs that makes it seem so. To take a more contemporary example, we may analyse the map "NATO Member and Partner Countries", and how it adopts projection, orientation so that the viewer adopts the position of NATO countries facing the EuroAtlantic partners in opposition. This inevitably encourages identification with the NATO space instead of the "other" bloc. This also gives an orientation as if the neighbour countries to NATO countries had to serve (or sooner /later are destined to serve) NATO purposes. Moreover, in this map you also see what sort of roles (Dialogue, Cooperation, etc.) and missions are given to each region by NATO (See Figure 1). 


\section{NATO MEMBER AND PARTNER COUNTRIES}

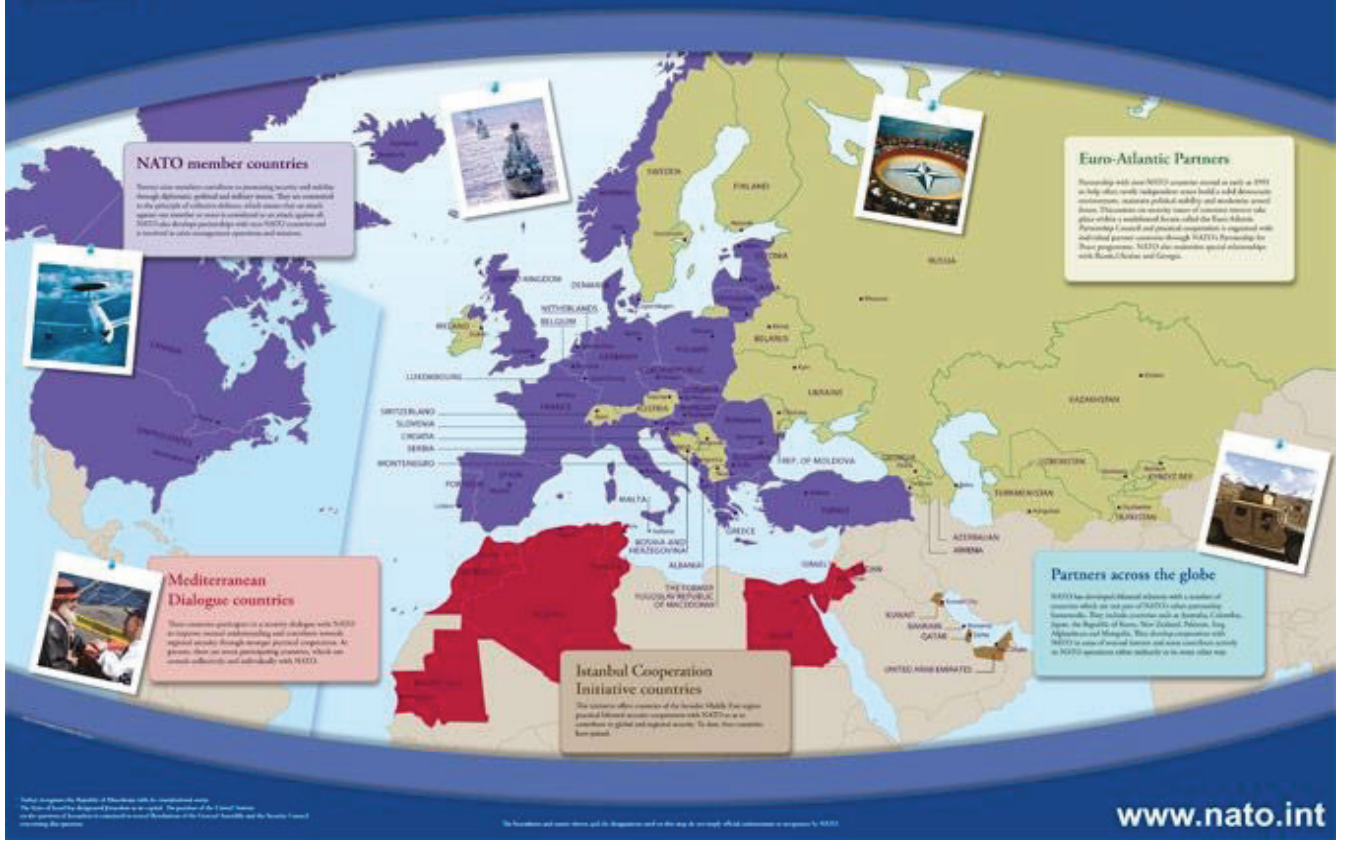

Figure I: NATO MAP: Source NATO archives, http://www.nato.int/cps/en/natohq/topics_8I I 36.htm (accessed I3th October 2017).

A critical map-reader should ask why a particular orientation has been chosen and what political purpose it serves. The examination of such maps helps us to deconstruct the mentality behind the governance/management of security, migration, energy, etc., but here we will be content to show that "a map is a not merely a map" but it reflects the ideology of its maker. On the map above we have a specific classification of the regions such as "Istanbul Cooperation Initiative Countries" printed in beige representing "the countries of the broader Middle East region practical bilateral security cooperation with NATO so as to contribute to global and regional security" (Bahrain, Kuwait, Qatar, United Arab Emirates) and Euro-Atlantic categorized as a major political actor in light green colour. Especially the relationship between NATO and "Euro-Atlantic partners" is defined in a hierarchic manner:

“To help often newly independent states build a solid democratic environment, maintain political stability and modernize armed forces. Discussions on security issues of common interest take place within a multilateral forum called the Euro-Atlantic Partnership Council and practical cooperation is organized with individual partner countries through NATO's Partnership for Peace program. NATO also maintains special relationships with Russia, Ukraine and Georgia”. 
This hierarchic discourse of "help" and "cooperation" is clearly seen here as if there is an unquestioned hegemony between the non-NATO countries and NATO members. This discourse seems to suggest that these countries are supposed take the member states as a model and serve the purposes defined by NATO. Regarding the Mediterranean region, this hegemonic discourse was softened to some degree defining the relationship in the form of "participation and dialogue" rather than "being in need of help from NATO". In the map above the Mediterranean region that is represented in red accommodates the dialogue countries, namely Algeria, Egypt, Israel, Jordan, Mauritania, Morocco and Tunisia. According to NATO, these countries "participate in a security dialogue with NATO to improve mutual understanding and contribute towards regional security through stronger practical cooperation". As the map underlines, these participating countries are entitled "to consult collectively and individually with NATO". It is clear that in this hierarchic discourse, Mediterranean partners are defined more on an equal basis compared to the other regions. This raises new questions and discussions over the spectrum of self-other relationships. As the discourse above exemplifies, NATO's perception of Mediterranean dialogue countries gives us more insights to discuss the role of this region in the demarcation between East and West.

In particular, the "Southern Mediterranean" identity and its position vis-à-vis the EU can be seen as an interesting case for an unusual self-other relationship. As has been argued by several scholars, the formation of an "other" can take many forms. The "other" does not necessarily have to take the shape of a subordinate, backward, or even dangerous identity as within Edward Said's influential study on the West and the Orient (Said, 1979). The other can also be constituted as equal or even superior to a (national) self, it can be located in a different time, and it can, for instance, be constituted as one's own historical past. The relationship between self and other can accordingly also be marked by enmity or amity, by admiration or indifference. The self can identify with the other or even submit to the other (Neumann 1996, Campbell 1998). We will come back and further argue about this relationship in the chapter below (EU's View of the Mediterranean) where we discuss the conceptions of the Mediterranean in the EU discourse.

\section{The Mediterranean as a "Pool of Identities"}

In this part of the study the primary focus will be the Mediterranean as the home for the emergence of "Eastern-Western" identities and how these identities shift according to the changing political conditions. In doing this we will basically take both the Turkish and European perspectives as different geographical imaginations. Historically speaking, the Mediterranean identity was significantly transformed while the Ottomans started to dominate the region; and it was equally so when the Empire was geographically shrinking and the Turkish State was born on the "Asia Minor" or Anatolian territories. Moreover, along with the changing conditions in world politics, the Mediterranean region gained new meanings for both "Eastern" and "Western" sides of the region. This brings about contested or sometimes contrasting narratives regarding the Mediterranean identity. In some political narratives the very definition of the Mediterranean perpetuates the East-West dichotomy and in others "Mediterranean identity" functions as an 
instrument to "escape westward" from any Islamic or "Eastern" attachments. For this reason this article assumes that the deconstruction of the various "uses of the Mediterranean" would help us investigate how different meanings, perceptions and political projections are at stake.

Historically speaking, the Mediterranean has always been a zone of encounter where different or antagonistic religions and cultures converge and diverge. Each cultural/political group developed an attachment to this region in its own way. There are remarkable studies that try to draw our attention to the "essentialist narratives" over how the "self-other" dichotomies are at perpetuated in both Europe and the Arab and Turkish Mediterranean (Gozzi, 2012, p. 13). In these narratives the different "uses" of the Mediterranean as a category of identification are changing according to the perception by different states, people and societies. For instance, in the eyes of an Arab society being Mediterranean can be synonymous with a Western identity, whereas for British society being Mediterranean can be perceived as closer to the Eastern type of identity.

It seems that the Mediterranean region is a key space where the concepts of West and East are constructed and reconstructed throughout the ages. On this point we should also recall that the very first uses of the concept of "West" referred to people, societies and states surrounding the Mediterranean, whereas the lands further to the East and South constituted the "East" (Hentch, 1992). The very idea of Europe is also developed upon the constitution of the Eastern ground with the Muslim conquests of Asia Minor, Malta, Spain and southern territories. While the category of the West shifted more further westwards with the emergence of the idea of "Europe", the people in the south of the Mediterranean Sea came to be included more in the category of the East. These developments also have a negative impact on the idea of a "Unified Mediterranean". Hence this unity was shaken by the changing political balance between dichotomous relations between East/ West and North/South in the region. Besides Braudel's (1972, p. 615-42) historical remarks, there are also numerous studies that confirm that these dichotomies are persistent:

"If the eastern Mediterranean was in the process of sliding slowly and unconsciously into dependence on the Westerners ... parallel to this hold of the West over the East, there was another conquest on the western side, the conquest of the South by the North" (Fontenay 1993, p. 52).

In order to understand different attachments and conceptions of the Mediterranean we need to see how these dichotomies (East/West and North/South) became functional (or sometimes dysfunctional) in specific examples. For instance, there remained a belief in the cultural identification with the Mediterranean in the Arab world: especially in Egypt and Lebanon the Mediterranean dimension of their identity is much more preserved than others (Salem 1997). Moreover during the 1950s some Lebanese nationalist thinkers claimed that they favoured the Mediterranean identification over other identities. Hence for some countries "Mediterranean identity" became a useful instrument to "de-tach" from the Arab/Islamic world while claiming affinity with Europe and the West. However, this identification was played down during the foundation of Israel when countries of the Arab league started to struggle with Israel (Salem 1997, 
p. 23-42). North African intellectuals have also favoured a similar Mediterranean identification as a way of highlighting the Maghreb's Arab Berber ethnic mix and underlining historical links with Europe in general and with France in particular. As Tunisia, Algeria and Morocco gained independence, there emerged non-European Mediterranean states enabling an intellectual discourse closer to this peculiar Mediterranean identity. So, Mediterranean identity became an alternative spatial representation, which is used by Maghreb intellectuals to demarcate their identity from the Mashreq other (Bilgin 2004, p. 273).

Hence one can argue that the Mediterranean identity card is put forward by the non-Western countries to identify with a more "favourable" or "powerful" image, namely the "Western" image. As we discussed in the NATO map above, this sort of identification would also be welcomed by the official NATO discourse since it classifies these countries as the "dialogue partners" in the Mediterranean. The uses of the Mediterranean identity as an "escape westwards" can be understood more clearly in the light of the discussion of Orientalism. As is well known, Said (1979) posited that the outsiders, (for Said the Western cultures) perceived the non-western lands and in particular the Orient as open and often virgin territory. It was there for to be captured and subjugated. Whether this was always the case or not, it does point to how such imagining became revenue for legitimizing actions. What is crucial here is that the very act of imagining becomes an apparatus and an expression of power. This power is the ability of colonizers to construct and objectify what they are seeking; they use it to erect their perceived reality. Apart from Said's dichotomized Orientalism, Makdisi in his article on "Ottoman Orientalism" argued that there are nuanced versions of Orientalism and some of them are formed outside Europe. Makdisi suggests “in an age of Western dominated modernity, every nation creates its own Orient" (Makdisi 2002, p. 768).

In this chapter we have tried to see how different geographical imaginations of the same geographical area produced different identities. Under this light we can claim that the various uses of Mediterranean identification form a continuum. It is apparent that the power relationships are the most effective in the construction of Orient/Occident. As far as Western dominated modernity and the Eastern identities are concerned, it is significant to note that these identities are mutually constitutive. However, the flexibility of these identifications is eventually bound by the political climate of the region. Hence depending on geo-strategic perceptions, Mediterranean attachments and identities became stretchy. This helps us to understand the above examples of how and why a once favoured Mediterranean identity was played down during the foundation of Israel. Hence the foundation of Israel led to a certain polarization between Arab and non-Arab identities in the region. So when there is a common threat, identities may unite to solidify the common "self" (i.e., the solidification of the idea of Europe against the Threatening Turk"), or possible identities may dissolve and highlight the nuances to differentiate themselves from "the similar others" as is in the case of Maghreb intellectuals differentiating from Mashreq. 


\section{Mediterranean in the Western Imagination: "Dramatic Geography and the Grand Turk"4}

In the Western imagination the Mediterranean was portrayed as the original setting of classical and scriptural histories, but also represented as a space of historical conflict between Christianity and other religions. Most importantly, the expansion of the Ottoman to Eastern Mediterranean (which is called the Levant in Western discourse) had an impact on the imagination of the Mediterranean in the minds of English subjects (Vitkus 2003, p. 35). The ways in which the fear of the "Grand Turk" and the accompanying threat of "turning Turk" shaped European culture have been studied from literary and historical perspectives.

In his Mediterranean traged, Othello, the Island of Cyprus ruled by Venice faces an attack and Shakespeare portrays the Turkish threat as invisible but terrifying. In the sixteenth and seventeenth centuries, the Europeans were both colonizers and colonized, and even the English felt the power of the Turkish threat to Christendom. In his analysis of Othello, Vitkus argues that according to Protestant ideology, the Devil, the Pope, and the Turk all desired to "convert" good Protestant souls to a state of damnation, and their desire to do so was frequently figured as a sexual/sensual temptation of virtue, accompanied by wrathful passion for power. Historicist studies of Othello show how Christendom was put at the centre of civilization, how it exploited the perceptions of a global struggle between the forces of good and evil, and producing a seeming binary opposition that in reality is complex and multifaceted. Vaughan's chapter "Global discourse: Venetians and Turks" makes apparent the importance of Turkey in the imaginative geography of Stuart England (Vaughan 1994, p. 13-34).

There are many examples regarding literary studies showing how the imagination of the "dangerous other" (any Islamic or Arab identity) is usually categorized as the "Turk". The fascination and fear of the exotic religions and the clear link with personal downfall were expressed in a number of early modern plays, perhaps nowhere clearer than in the dramatist Robert Daborne's 1612 play "A Christian Turned Turk" in which the audience follows an English sailor who became a pirate in the Mediterranean and later turned Turk after falling in love with a beautiful Turkish woman. In the play his situation illustrates both the fascination of the exotic as well as the fear of Islam in England at the time.

It would be appropriate to bear in mind here that the image of the "Turk" had a great role in the reconfiguration of Mediterranean space. As the Argentinean writer and philosopher Borges states "the negative image of Carthage is the work of the Romans and in the same spirit the horrible image of the Turk is the product of Western Europe" (Kumrular 2009, p. 27-46). This image was travelling throughout the Mediterranean, at every step polished and revived by new stories turning into a Turkish Obsession-Ossessione Turca (Ricci 2002).

Historically speaking, there are some periods when the image of the "threatening Turk" lessened. The turning point of the relationship between European powers and the Ottoman is marked by

4 For more detailed study of the term “dramatic geography” see Laurence Publicover (2017). 
the Treaty of Carlowitz (1699) representing the first example in which the Turks were invited to participate in the European Congress; despite the decline of the military threat it was perceived as a cultural threat. As Neumann argues "the empire was seen by many as an incarnation of the old religious war, the former infidel metamorphosed into "barbarian". That means, "civilization" seems to step into the shoes of "religion" in Europe's differentiation from the "Turk" (Neumann 1996, p. 51) This very term "civilization" with its embedded religious connotation paves the way for the "civilizational geopolitics" that will be discussed in detail below in the discussion of the "Mediterranean from EU's Perspective" (section D).

So far we have tried to give an historical and ideological picture of the Mediterranean both as a space for multiple identities and also a space for the demarcation of the construction for EastWest, Self and Other. The coming chapters will focus on the Islamic heritage and "Turkish" side of the Mediterranean story.

\section{Islamic Mediterranean Heritage}

The vast literature on the Mediterranean region suggests that it is hard to confine its perception to one dimension. So there is not one fixed definition of the Mediterranean region, it has many dimensions. As Braudel (1976, 1, p. 473) claimed, "space was the enemy number one in the Mediterranean. In this enormous geography extending from Gibraltar to Syrian coasts Ottomans played a significant role in the transformation of the notions of "our place" and "theirs", "near" and "far" as well as "East" and "West".

The meeting of Islamic culture with the Mediterranean region dates back to the mid- $7^{\text {th }}$ Century. When the Islamic forces reached the Northwest of the Mediterranean Sea it changed the whole cultural and political climate of the region. One of the preliminary authors who wrote about the Mediterranean was Mes'udi (896-965) who mentions that Harunürreşid, the Khalifa of the Abbasid had an immense plan to build a canal (modern-day Suez Canal) that would connect the Red Sea to the Mediterranean but he was concerned about any possible military attack on Muslim Pilgrims by the Byzantine forces. So here we can also detect that the "othering discourse" is heavily nourished by military / security reasons. The Mamluk politician and historian Nüveyri (1332) narrated that the Mediterranean region had 170 islands that were prosperously developed and zoned by the Franks and later were destroyed by the military attacks of Islamic forces ${ }^{5}$.

Islamic geographical terminology about the Mediterranean had kept both Latin terms Mediterraneum Mare and Internum Mare. In Late Latin, in referring to the sea, Medi-terra originally meant "in the middle of the earth" rather than "surrounded by land", because to the Mediterranean cultures without knowledge of much of the earth, the Mediterranean Sea was in the centre of the world. The word mediterranean is first recorded in English, in 1594, as the name of the sea. In Islamic geographical knowledge Mediterraneum Mare is defined as the "el Bahrü'l

5 Encyclopedia of Islam, 1960, Brill publications, Vol: 2; p. 231. 
Mutavasst" (the sea between the mainlands) and the Internum Mare is defined as "El Bahrüd dahili". However in popular usage these terms did not take much stock; usually it was called "Bahrür Rum", that implies "the European shores" historically referring to East Roman heritage. Regarding the mainland bordering the Mediterranean Sea, there were several names such as Bahrü'l-Endelüs (Andalucian Sea), Bahrü'l-Mağrib (Sea of the Magreb), Bahrü'l-Ifrîkıyye (Sea of Tunisia), Bahrü'l-İskenderiyye (Sea of Alexandria), Bahrü’ş-Şam (Sea of Damascus), Bahrü’lKostantiniyye (Constantine's Sea) and ve Bahrü'l-Efrenc (Sea of the Franks).

It is important here to see how the Ottoman Empire approached the region in the military context since the Ottoman navy was famous for its military glory from around the late 11th century to the 18th century at least. The geography of the Ottomans extended from the further western parts of the Mediterranean to the Indian Ocean and the Strait of Hormuz ${ }^{6}$. The success of the Ottomans is usually related to their contribution to the wider subject of geography and nautical science. This aspect, however, is little mentioned in the literature. Until recently, historians were mostly preoccupied with the dramatic story of the geographical discoveries and oceanic voyages undertaken from the late 15th century (Zaimeche 2002). However, several scholarly works have been published recently highlighting the contribution of Ottoman scholars to the development of cartography, geography and nautical science. Special attention was given to Ottoman maps, whether they be the charts of the Mediterranean or world maps, especially those designed by Piri Reis (Hess 1969:70).

The Kitab-i Bahriye (Book of Navigation) by Piri Reis (1465-1553) is worth mentioning here as it is one of the most famous pre-modern books of navigation. It contains detailed information on navigation as well as extremely accurate charts describing the important ports and cities of the Mediterranean Sea. Rich in detailed information on the major ports, bays, gulfs, capes, peninsulas, islands, straits and safe anchorages of the Mediterranean Sea, it is also full of navigation techniques and navigation-related information on astronomy. The book also includes information on the local people of each country and city, and the curious aspects of their culture. The book was originally written between 1511 and 1521, but it was revised with additional information and better-crafted charts between 1524 and 1525 in order to be presented as a gift to the Ottoman Sultan Suleiman the Magnificent. Piri Reis drew these charts during his travels around the Mediterranean Sea with his uncle Kemal Reis. The revised edition of 1525 has a total of 434 pages and contains 290 maps. The maps contain detailed information on important ports and cities of the Mediterranean, where we can see how the areas of water are circumscribed by imposing and colourful linked mountain chains (the Alps, the Apennines, the Balkans, the Pyrenees, without forgetting the eminent Hellas and Lebanon) as if they were utopian fantasy kingdoms.

Below there is a map showing how Piri Reis depicted Europe and the Mediterranean region (See Figure 2).

6 See, for instance, M. Longworth Dames (1921); E. Denison Ross (October 1921); E. D. Ross(1922). 


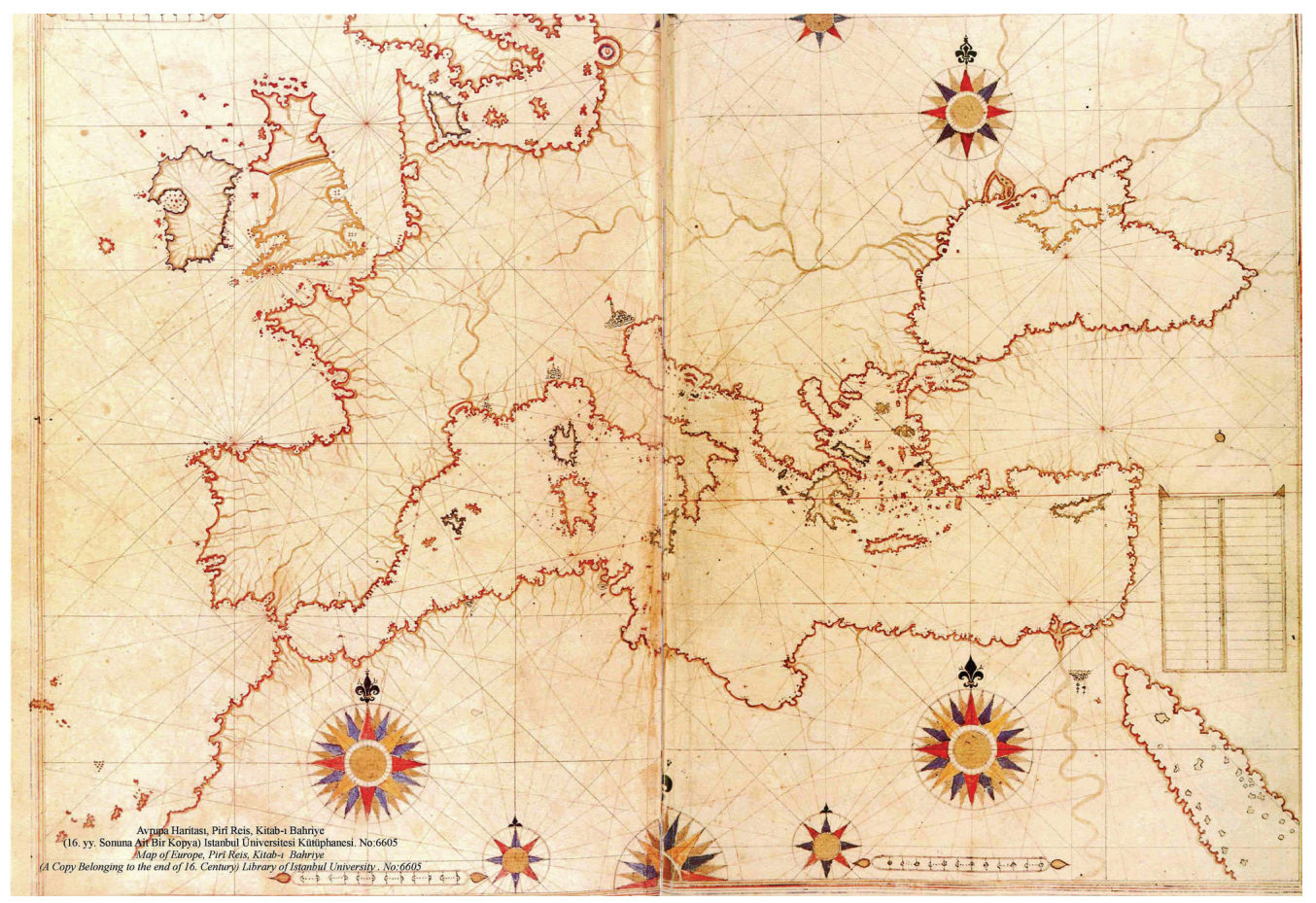

Figure 2: Map of Europe and the Mediterranean region by Piri Reis. The map shown is from the 16th century book Kitab-1 Bahriye. (Source:Library of İstanbul University, no 6605).

According to Piri Reis, the borders of the Mediterranean are described as starting from the North of the Bosphorous including the Marmara and Aegean Seas until Gibraltar Bay. This area was composed of four regions, namely the sea of Rum (European coast), the sea of Spain, the Black Sea and Bahr-i Ebyaz (White Sea, meaning Akdeniz in Turkish that refers to the Mediterranean Sea). In his definition, the Bahri Ebyaz region is composed of the Arabs, Franks, Rum and people of Maghreb. After all, the Mediterranean is a vast space that separates Europe from Africa and where cultures co-exist from contrasting periods of history (Roman Christianity - what is commonly called the West, the ancient culture of Greece, Constantinople, conquered by the Ottomans in 1453, as well as Islam, the Phoenicians, the Persians, the Assyrians, the Chaldeans and even the Sumerians).

Modern world maps politically and physically rest on an idea of boundary since territories are demarcated either by political relations or by physical limitations. Waters and mountains are the usual natural boundaries in the modern mindset. However, Mediterranean waters reflect an unusual character here, since "it is the only body of water that represents historical connectedness and unity” (Kolluoğlu \& Toksöz 2010). We can see this unified perspective in the ancient maps such as in Piri Reis. 
The perception of unity and multiplicity as a characteristic was preserved in the Islamic perception of the Mediterranean for many years. Though there are different definitions and political descriptions of the region in the Islamic world, they share the idea that the Mediterranean Sea as the womb of multiplicity. It can be stated that from the Islamic point of view, the Mediterranean is perceived as a space where "opposites join but do not merge"; some authors and interpreters take the verses of the Quran (El Kehf 18/6061, er-Rahman 55/19) as a reference to define the Mediterranean sea as the "Merace'l bahreyn", (Sea where two waters meet), meaning the place where the sweet and sour waters reach each other (Kadığlu 2016, p. 187). This imagination paves the way for various "readings" of the Mediterranean but within the limits of our concern here, we will be content to mention that in the Islamic imagery the Mediterranean is conceptualized as a home of opposites, where they co-exist but do not "mingle".

Ibn Khaldun had realized the importance of the Mediterranean not only as a space for unity and identity but also for power struggle. According to him, there was once a Golden Era of Muslim maritime power in the $8^{\text {th }}$ and $9^{\text {th }}$ centuries when the Muslims ruled the Mediterranean. Besides control as an expression of power against Christians, it is also an opportunity to unite the Muslim world. By the $14^{\text {th }}$ century, Ibn Khaldun claims "Muslim powers have turned away from the sea, becoming vulnerable to cycles of the rise and fall in the land-based Bedouin Dynasties (Fromherz 2010, p. 20).

\section{Mediterranean from the EU's Perspective}

It is well known that Mediterranean space during the time of the Roman Empire was the centre of world politics, whereas now it has shifted to the periphery in EU politics and the EU's construction of the Mediterranean has also transformed over time. It is basically because of the changing conditions in the international and regional contexts. There is an emerging critical literature on the Eurocentric Mediterranean discourse ${ }^{7}$ that is trying to decipher how the definition of the Mediterranean region varied through time, and how it is spatially categorized within the EU space.

When we look at the interest of the EU in the Mediterranean during the 1970s (GCC, AMU) the Euro-Arab relations did not grow further possibly due to the mistrust caused by some EU states' colonialist backgrounds and also other regional security dynamics (Jawad, 1992). As further research suggests, the definition of the Mediterranean by the European Community during the Cold War deviated from the EU's definition during the Euro-Mediterranean Partnership (EMP), also known as the Barcelona Process, and a new conception emerged after the September 11 attacks - to be followed by the Istanbul, Madrid and London attacks - mainly based on security concerns. Recently, the Mediterranean has again been reconfigured along with a different security

7 On the Euro-centric focus of European Studies and studies on the Mediterranean/Middle East, see Cebeci (2012), Bilgin (2016), Onar and Nicolaïdis (2013) 
focus, particularly based on threat perceptions related to the refugee crisis and ISIS (Cebeci \& Schumacher 2016):

The MEDRESET policy report (2016) shows that the EU constructs the Mediterranean space mainly through three discursive practices, notably

1) "The Mediterranean as a diverse geopolitical space"

2) "The Mediterranean as a dangerous space"

3) "The Mediterranean as a space crucial for EU interests".

In the contemporary world, when the EU security discourse refers to Mediterranean problems the aim is either to solve it so that this problem would not threaten security directly (that is through military or terrorist threats) in Europe, or indirectly (that is through increasing migration/ restlessness among the Mediterranean diaspora in the Union (Bilgin 2004, p. 274). Bilgin further argues that the discourse on security of the EU in the 1990s shifted towards what she refers to as Agnew's term "civilizational geopolitics".

To recall what civilizational geopolitics means briefly, we need to clarify Agnew's conceptual framework regarding the 'ages of geopolitics'. Accordingly, an age is perceived as a period in which the modern geopolitical imagination has shown distinctive features and relations to practice. The first, dominant in the $18^{\text {th }}$ and early $19^{\text {th }}$ centuries, was a "civilizational geopolitics", in which Europe's unique civilization compared to the newly discovered rest of the world played a central role. The second, dominant from the late $19^{\text {th }}$ century to 1945 , was a "naturalized geopolitics", in which the 'natural' character of states as predators and competitors assumed a key position. The third, operational during the years of the Cold War, was the "ideological geopolitics" based on dividing up the world between competing ideas about how best to organize political and economic life i.e., 'socialism' versus ‘capitalism' (Agnew 1994, p. 12).

When we use the above-mentioned framework to analyse the EU's perspectives and Mediterranean policies we may see more clearly how and why the EU adopts certain attitudes under specific political conditions. Especially during the Cold War, the EU made use of the security umbrella provided by NATO and adopted a peculiar approach to security building a larger agenda (such as economic, environmental, human rights) without labelling them as security issues. This was a way to deal with major problems (such as migration, human trafficking, drug trafficking) without being entangled in the East-West confrontation (Bilgin 2004, p. 271-75). However, another confrontation that EU-Mediterranean relations have to deal with is the security and democracy dilemma. It is often concluded that the EU has privileged security and regime stability in the short run, at the expense of the long-term goal of sation and propagation of human rights norms. As far as the Southern Mediterranean is concerned, the most important issue for the EU is cooperation on issues of illegal immigration, organized crime and terrorism, while also seeking to contain fears from the Southern Mediterranean states that the EU would impose its own political system and values on the Mediterranean states or even employ in outright interference. Moreover, as 
Malmvig argues (2004, p. 6), the EU has also itself feared that too strong pressures for political reforms may lead to aggressive and hard transition processes, or result in Islamists taking over government power (Spencer 2002).

These studies analysing the security approach by the EU argue that there are two conflicting security discourses: a liberal reform discourse and a cooperative security discourse. The simultaneous presence and intermingling of these two discourses have meant that the EU has wavered uneasily between different priorities and logics in its Mediterranean policy. This gives EU policies a rather schizophrenic spirit, while at the same time arousing suspicions on the part of Arab member states about the real intentions and goals of the EU in the region (Malmvig 2004).

The Mediterranean as defined by Europeans shows not only temporal variation, but many European actors also conceive of it in different terms. For the Member States of the EU, which are located in the Mediterranean space, it is part of their identity -although some continue to see its southern shores in terms of the self-other dichotomy. On the other hand, for some nonMediterranean EU Member States, even the EU's southern Member States represent Europe's periphery and the latter have sometimes been subjected to an "othering" discourse, mainly because of their cultural, social and economic characteristics. This recalls the ideological geopolitics that Agnew defined.

However, this ideological geopolitics by the EU towards the non-Mediterranean countries seem to switch into a version of civilizational geopolitics when it comes to the partners in Mediterranean region. As Malmvig (2004) argues within the cooperative security discourse, the Mediterranean partners are indeed articulated as different from Europe/the EU, and they are, in fact, explicitly named as an "other". Yet, this "other" is not constituted as backward or inferior, or as a threat to fight or transform. The relationship between the EU and the Mediterranean is rather articulated as a partnership based on equality and respect; free from notions of superiority/inferiority. It is, hence, not a radical other, but what could be called an "equal other", which is encouraged. As we see in the Barcelona Declaration, the partnership is based on "due regard for the characteristics, values and distinguishing features peculiar to each" (Barcelona Declaration, 1995). Each people "has its own values, customs, language and beliefs", but these differences are not sources of enmity or conflict, but of enrichment (9890/03 Press 151, p. 13).

"The ultimate goal of the dialogue should not be to change the Other, but rather to live peacefully with the Other" "Conscious that the values of dialogue, tolerance and respect for the Other $[\ldots]$ constitute an important factor in bringing closer together cultures and civilizations".

According to Malmvig (2004), these presumptions of the equality of the Other and the possibility of mutual enrichment are further justified by references to a shared Mediterranean past, in which "our" different cultures and religions were born: "The Mediterranean region is the birthplace of 
several great civilizations of the history of the world in which originated the three monotheistic religions" (Holm, 2004). By referring to this common past, the Other, although expressed as different, is at the same time situated very close to the Self (Europe). That can be termed here as an "authentic version of the Self". Hence the shared Mediterranean past becomes a type of "mother-figure", which has given birth to equally grand and civilized children. Now as adults, the "siblings" have to remember their common roots. They are to be brought closer together and learn from one another, yet they respect each other's autonomy and difference (Malmvig 2004). This interpretation supports the argument that the EU's discourse towards Mediterranean partners holds civilizational geopolitics as an invocation to recall the common culture and civilization which is again represented by European ideals.

As far as Turkey is concerned, things are more ambivalent. In Europe's typology the relations can be characterized as a mixture of civilizational and naturalized geopolitics. Due to Turkish/Islamic culture and values it is exposed to an "othering" discourse by the EU, however it holds a very special place for its specific geographical location as being by far the main springboard country to the EU. For instance, as of February 2017 Turkey has been hosting 2,910,281 registered Syrian refugees; in addition to the registered ones, it also hosts more than a million unregistered refugees mostly coming from Syria, Iraq and Afghanistan. According to the EU Facility for Refugees in Turkey, it is hosting the largest refugee population in the world, ahead of both Lebanon and Pakistan (European Commission 2017c). In some border cities like Kilis, the refugee population even exceeds the local population.

It is widely argued by scholars that Turkey-EU relations turn Turkey into a hub for irregular migrants. The 'politicization', 'securitization' and 'economization' of international migration and asylum in Europe also makes asylum seekers find more secure options, like moving to some third countries and countries of transit such as Turkey. The possibility to be used as a buffer zone makes Turkish authorities concerned that this might turn Turkey into a country of first asylum, and for this reason Turkey insists on maintaining the "geographical limitation"8 in its migration policy (Öner 2013, p. 217).

Recently, in an attempt to end "irregular migration" from Turkey to the EU, an agreement was signed between Turkey and the EU on $20^{\text {th }}$ March 2016. According to the deal, Turkey would accept one refugee from the Greek Islands who used Turkey as the route to Europe; in exchange, a Syrian asylum seeker in Turkey would find a home in Europe. (Görgülü and Dark 2017, p. 9). It is apparent that the EU's border control is also an important element of concern, "We do not know at present what is going on in the Mediterranean Sea. We do not know, nor do the member states" Edgar Beugels, head of research and development at Frontex, told reporters in Brussels (18 ${ }^{\text {th }}$

8 Turkey retains a geographic limitation to its ratification of the 1951 U.N. Convention on the Status of Refugees ("Refugee Convention"), which means that only those fleeing as a consequence of "events occurring in Europe" can be given refugee status. Regardless of any geographical limitation under the Refugee Convention, Turkey must still abide by the principle of non-refoulement (that no one may be returned to a country in which he may face persecution), which is binding in all cases. For details of Turkey's reservation, see http://www.unhcr.ch/refworld/ refworld/legal/instrume/asylum/51engsp.htm. 
March 2013) ${ }^{9}$. This means that spanning some 2.5 million square kilometres, the Mediterranean Sea remains largely outside the surveillance scope of the Member States and the Warsaw-based EU border agency Frontex.

From the EU side, the selection criteria for asylum seekers were quite vague. As for Turkey, visafree travel for Turkish citizens was the big prize for taking back refugees and economic migrants from Europe. Besides being problematic from the human rights perspective, the deal had many shortcomings and it soon became clear that its full-scale implementation would never be possible. Therefore, the Turkey-EU migration deal did not ultimately succeed and only 6,907 Syrian refugees have been relocated from Turkey to the EU within its mandate (European Commission 2017a and 2017b). Despite this, improving cooperation with Turkey on the refugee crisis remains a priority for the $\mathrm{EU}$.

Lesser (2016) argues that developments in the Eastern Mediterranean now have a central place in the perceptions of Northern and Western Europe, including Germany. To the extent that Berlin continues to develop a more active and forward leaning external posture, the effects of this will be felt, first and foremost, on Europe's southern periphery where crises abound. Germany's central role in dealing with Europe's refugee crisis, including negotiations with Turkey and the leadership of NATO's maritime operation in the Aegean, is the clearest example.

So far this paper has discussed the Mediterranean space as seen by the EU and from a "Western" angle. The coming chapter will look at the same region from a different angle and we will try to see how Islamic culture and the Ottomans saw the Mediterranean. Furthermore Turkey's view of the Mediterranean region will be discussed along its geo-political reading of the region.

\section{Turkish Attachments/Detachments vis-à-vis the Mediterranean}

The Mediterranean identity for Turkish politics is ambivalent. This ambivalence is historical. In order elaborate on this we need to look at the historical framework. The overall debate over identification during the dissolution of the Empire had its own multilayered problematics. However, we can recapitulate the historical roots of these problematics as the tension of three main currents of thought: Westernism, Islamism and Turkism. When the Turkish Republic was born under the leadership of Mustafa Kemal Atatürk, Westernization came forward as a dominant ideal. For Atatürk and the leading elite, Europe and the values it represented were identical to modernization and they believed that it was possible for a newborn secular country to redefine its past, its roots and reform its traditions along Western lines. While the Ottoman Empire can be territorially considered a European state to some extent, it has never been perceived as part of the European circle. As Agnew (1994, p. 94) pointed out, from the late $18^{\text {th }}$ century onwards "the otherness of Turks" had been a basic barrier to their participation in civilizational geopolitics. As 
Neumann remarkably argues, though Ottomans were the famous "sick man of Europe" they were not perceived in a similar way in Asia (Neumann 1999, p. 55-9).

Therefore it was important for newborn Turkey to relocate its identity both ideologically and geopolitically. The interwar era was a crucial period for Turkey to gain international recognition as a modernizing country ${ }^{10}$. The republican elite and foreign policy builders had invested so much energy to take a place within the community of western civilization and they tried to show that the Islamic faith is not a barrier to taking this place; rather it has all the qualifications to be included in the circle of western civilization. This is most likely why the geographical role of Turkey is defined as a "bridge" that has been used and reinterpreted for many years. "Bridge" has become the metaphor describing contemporary Turkey, however the Turkish political elite used "door," "latch and key," "crossroads," and "gate" to describe not only Turkey's hybrid location and past, but also the role or function to which it aspired internationally (Yanık, 2009, p. 536537). When the leading Turkish elite react against their European counterparts' unwillingness to include Turkey in the EU, they equally react against being portrayed as a Middle Eastern or Mediterranean country. Though Europeans did not include Turkey in terms of identity, they did not exclude it in terms of political-economic sense. Since 1963, when Turkey signed the treaty of association with the European Community, the relations have expanded its span and activity.

Given the context of the above-mentioned self-other relationship and the discussion over Orientalism, it is worth rethinking how Turkey locates itself with respect to the Mediterranean. We have already emphasized that Turkey's relationship to the Mediterranean seems to be highly determined by mainly two competing ideologies namely Westernization and Islamism.

As a general tendency, Turkish policy-makers were locating Turkey as part of the Western world rather than part of the Middle East or the Mediterranean. Especially in the young Republican Turkish political discourse (that is in favour of Westernization), there is a remarkable attitude that puts Turkey in the circle of Western civilization. This attitude puts a strong boundary between the Mediterranean (meaning the Eastern) and Turkish identity. (Bilgin, 2004, p. 278). This attitude was preserved towards the European Union and the discussion over Turkey's membership. Actually the whole discussion over the EU and Turkey has become a framework that perpetuates the powerful dichotomization of the Western type of self-other.

As Görgülü and Dark (2017) argue, being geographically close to the EU, Turkey has been under the influence of several Mediterranean policies of the Union including the Global Mediterranean Policy (1972), the Euro-Mediterranean Partnership (1995), the Southeast Europe Stability Pact (1999), the EU Strategic Partnership with the Mediterranean and the Middle East (2004) and the European Neighbourhood Policy (2004). Turkey has been involved in these initiatives with different levels of interest. However, its participation in the above-mentioned forums has never secured an elevated degree of junction between Turkey's foreign policy and the Common Foreign and Security Policy (CFSP) of the Union, especially when the political and security dimensions

10 For a detailed study on Turkish Mediterranean Politics in the Interwar Era, see Güvenç S. \& Barlas D. (2010). 
of the initiatives were weakly developed. However, a practice of dialogue has been established between the two sides and this has created a productive ground for rapprochement.

One may also argue that Turkey's foreign policy decisions towards the Mediterranean have been under the shadow of the EU membership process, the Cyprus question, debate over energy resources, relations with Greece and the conflicts of the Middle East. Moreover, the lack of a broad definition of the Mediterranean region in Turkey's strategic thinking paves the way for its fragmented perception; that means the region is perceived through separate dynamics including the Middle East, Greece and Cyprus, the Balkans, and Europe. This portrait also confirms that in Turkey's geopolitical thinking, the Eastern Mediterranean hosts numerous security concerns as well as economic opportunities essential to Turkey's nationwide interest.

Görgülü and Dark (2017, p. 5) argue that the most chronic problems of Turkey's foreign policy, like the Cyprus question and the relations with Greece over the Aegean Sea, are in fact Mediterranean issues. However, Turkey has treated them as separate foreign policy problems rather than a part of its regional Mediterranean policy. In other words, Turkey's foreign policy has preferred to deal with the issues on the Mediterranean distinctly instead of constructing a single and unified Mediterranean policy. In the words of a Turkish diplomat "the Mediterranean has never been conceptualized as a totality in Turkish foreign policy” (Tayfur 2001). In other words, there is no single comprehensive definition or conceptual appreciation of the Mediterranean region in Turkish foreign policy. There is no single desk or department in the Ministry of Foreign Affairs that deals solely with the Mediterranean region and Mediterranean issues. Instead, the Mediterranean region is under the umbrella of different functional departments.

In general, the Turks perceive the Mediterranean region as being composed of the Middle East, Greece and Cyprus, the Balkans, and Europe. This means that "the Mediterranean" really means the "Eastern Mediterranean" in Turkish foreign and defence policy. This is because the Eastern Mediterranean presents a variety of problems that are perceived as important threats to Turkish territorial integrity and the country's vital interests. The problems with Greece and Syria, the Cyprus problem, the Arab-Israeli conflict and its chain impacts in the region constitute the main preoccupations of the Turkish foreign policy establishment in the Mediterranean overall.

As a result, it may be argued that Euro-Mediterranean co-operation is an ambitious and comprehensive EU regional project. As noted above, however, mainstream Turkish attitudes are not very enthusiastic about the Euro-Mediterranean Partnership (EMP) programme. Turkish policymakers do not conceal their indifference towards the EMP. Indeed, "from the beginning, Turkey has been an affiliate to the programme but as an unwilling partner." It may seem strange, nonetheless, that a country leading various initiatives aimed at regional cooperation in its region such as Turkey should fail to express enthusiasm for the EMP (Tayfur 2001).

According to some expert views, the Eastern Mediterranean is the region which will determine the future of the international security order. During the Cold War, the region was a centre of sporadic crises against a setting of multiple unresolved disputes - Lebanon, Cyprus, Greek-Turkish 
friction, and of course, the Israeli-Palestinian conflict. Today, the Eastern Mediterranean has moved from the periphery to the very centre of global concerns. The land and sea space spanning the Levant, the Aegean, Egypt, and onward to Libya, is set to be a zone of persistent chaos and conflict. Weak or collapsed states, direct and proxy wars and a confluence of great power stakes are all part of the equation - threatening the security of societies and individuals. NATO, the EU, and others, including Russia and China, are now compelled to address the challenges of strategy in the Eastern Mediterranean. In the midst of this pervasive tension, there are a few positive opportunities, including the potential for a Cyprus settlement, Turkish-Israeli reconciliation, and cooperation regarding the region's energy resources. Taking advantage of these opportunities will be critical for Turkey and the region (Lesser 2016).

Under the insecure conditions in the Eastern Mediterranean it seems that Turkey has to go beyond strengthening its core defence partnerships. With some three million refugees already in Turkey, Ankara has as much of a stake in successful EU-Turkey cooperation on this front as Brussels perhaps more. There is now a reasonable chance for a settlement of the Cyprus dispute. Success on this issue would be transforming for Turkish-EU relations, EU-NATO cooperation, regional energy cooperation, and in many other considerations. It would be a very positive improvement in the troubled region. It might also be the medium for Ankara and Athens to move beyond their customary détente, to resolve long-standing air and sea space disputes in the Aegean debates that continue to restrict maritime cooperation and resource development. Moreover, the normalization of Turkish-Israeli relations is long overdue. It is most unlikely that this relationship will return to anything like its former strategic character, but the costs of estrangement are greater in a vaguer and conflict-prone region, and there are important shared interests to pursue, from energy trade to tourism and defence (Lesser 2016).

\section{Conclusion}

This paper attempted to decipher the various perceptions and uses of the Mediterranean region under the light of the Eastern and Western political imaginations. It argues that the Mediterranean region with its long multicultural history and vast geography is a good example to show how the same space is perceived and politicized by contested narratives. These narratives are produced by Eastern or Western geographical imaginations that have historical and political implications. Moreover these attachments are based on different assumptions that configure the Mediterranean sometimes as a womb of sibling identities, sometimes as a battlefield of antagonistic actors. Thus different uses of Mediterranean identity depend on who, when and why questions. As we have discussed above from the perspective of the non-European Mediterranean countries, Mediterranean identity can be used as an escape westwards allows a reorientation of identity by detaching the possible links with Islam, Arab or any identity with Eastern connotations. In the Turkish case, the Mediterranean identity does not produce the same meaning. Rather than signifying the West, it is associated with an Eastern identity that traditional Turkish discourse is unwilling to embrace. According to this perspective, the very term civilization cannot be equated 
only with Westernization, hence Islamic creed cannot be a hindrance to gainingacknowledgement by the civilized world. On this point both Said's and Makdisi's discussion of OrientalismOccidentalism provides a useful framework to understand the various uses of Mediterranean identity as a signifier of western/eastern progressive-modern/backward-premodern meanings. Moreover Makdisi's powerful argument that "in an age of Western dominated modernity, every nation creates its own Orient" helps us here to make sense of the Turkish reactive attitude against the EU's exclusory practices. Turkey here does not even allow itself to be categorized as "Mediterranean" since it reconstructs an "Orient" along Mediterranean identity that may sound like a mimicry of Western discourse that estranges the East. This is why for Turkey any attachment with Mediterranean identity seems like a disappointment to be acknowledged by the West. However it needs further discussion since the ruling party (Justice and Development Party) discourse in the 2010s seems to be developing new directions towards non Western alternatives to attach with.

The dichotomies such as East-West, Orient-Occident, Self-Other are reproduced here in different forms and from different angles. These dichotomies produce their own geographical narratives that are mutually constitutive. The Mediterranean is the very space where contrasting identities meet, co-exist and constitute each other. For the European discourse. The Mediterranean can be pictured as a womb by referring to the common past with the "Other". Although it is not Europe, is at the same time situated very close to the Self (Europe). The Mediterranean may be called an authentic/primitive version of the Self. Hence the shared Mediterranean past becomes a type of "mother-figure", which has given birth to "equally grand" and "civilized" children. Western narratives on the Mediterranean are generally is based on the "uncivilized enemy" usually characterized as the "Turk". As we can see in Shakespeare's Othello, one of the classical texts of Western literature, the fear of the "Grand Turk" and the accompanying threat of "Turning Turk" are there to coagulate European identity and culture.

As a result, this paper argued that to understand how is it possible for the very same Mediterranean to refer to different/often contrasted worlds of meaning we need to think about geographical imagination and the mindset that regulates this imagination. Here, critical geopolitics allows us to make sense of seemingly contradictive uses of the Mediterranean and helps us to show in what ways they are justified on their own geo-logic. So both the EU's and Turkey's attitudes towards the Mediterranean must always be re-evaluated along the fundamental discussion over civilizational, ideological and naturalized geopolitics respectively since these attitudes are mutually constitutive and have their consequences on vital issues such as the securitization of migration and discussion over further cooperation on both energy and security issues. 


\section{References}

Agnew J. (1994a). The Territorial Trap: The Geographical Assumptions of International Relations Theory. Review of International Political Economy Taylor \& Francis. 1(1) 53-80.

Agnew, J. (1998b) Geopolitics: Re-visioning World Politics, London: Routledge.

Barcelona Declaration (1995). Adopted at the Euro-Mediterranean Conference, 27-28 November 1995. Available from https://ec.europa.eu/research/iscp/pdf/policy/barcelona_declaration.pdf on 22.11.2017.

Bilgin P. (2004). A Return to 'Civilisational Geopolitics' in the Mediterranean? Changing Geopolitical Images of the European Union and Turkey in the Post-Cold War Era. Geopolitics 9 (2), 269-291.

Bilgin, P. (2012). Turkey's ‘Geopolitics Dogma’. In S. Guzzini (Ed.), The Return of Geopolitics in Europe? Social Mechanisms and Foreign Policy Identity Crises (Cambridge Studies in International Relations, pp. 151-173). Cambridge: Cambridge University Press

Bilgin P., Durgun S. \& Yeşiltaş M. (2015) Türkiye Dünyanın Neresinde? İstanbul: Koç University Publication.

Braudel F. (1972). The Mediterranean and the Mediterranean World in the Age of Philip II, (Trans by Sian Reynolds) Vol.2. New York: Harper Collins.

Campbell D. (1998). Writing Security. United States Foreign Policy and the Politics of Identity, Minnesota: University of Minnesota Press .

Cebeci M. \& Schumacher T. (2016). “Deconstructing the EU's Discourse on the Mediterranean”, in MEDRESET Methodology and Concept Papers, No. 2. Available from http://www.medreset. $\mathrm{eu} / \mathrm{?}=13238$ on $12,12.2017$

Cebeci M. \& Schumacher T. (2017). “The EU's Constructions of the Mediterranean (2003-2017)”, in MEDRESET Working Papers, No. 3. Available from: http://www.medreset.eu/?p=13294 on 13.12.2017

Encyclopedia of Islam (1960) Bearman P.J et al (Eds.) Leiden Brill publications, ( 2) 231.

Fontenay, M. (1993). 'The Mediterranean, 1500-1800: Social and Economic Perspectives', in Victor MalliaMilanes (Ed.), Hospitaller Malta, 1530-1798: Studies on Early Modern Malta and the Order of St. John of Jerusalem, Mireva Publications.

Güvenç S. \& Barlas D. (2010) Turkey in the Mediterranean during the Interwar Era:Tthe Paradox of Middle Power Diplomacy and Minor Power Naval Policy, Bloomington Indiana: Indiana University Press.

Fotiadis P. (2008). “The Strange Power of Maps", School of Sociology, Politics, and International Studies University of Bristol, Working Paper No. 06-09.

Fromherz A. (2010). Ibn Khaldun: Life and Times. Edinburg: Edinburg University Press.

Gozzi G. (2012). "Prospects of Cooperation and Processes of Democratization in the Mediterranean", in Gustavo Gozzi (Ed.). The Future of the Euro-Mediterranean Relationships. Bologna: il Mulino.

Görgülü A. \& Dark G. (2017). Turkey, The EU and The Mediterranean, in MEDRESET Working Paper No:7.

Gregory D. (1994) Geographical Imaginations. USA: Wiley.

Harley J. B. (1988) “Maps, Knowledge, and Power," in Cosgrove D. and Daniels, S. (Eds.) The Iconography of Landscape (pp. 277-312) Cambridge: Cambridge University Press.

Hess, A. C. (1969). The Evolution of the Ottoman Seaborne Empire in the Age of Oceanic

Discoveries, 1453-1525. The American Historical Review, 75 (7) 1892-1919.

Hentch T. (1992). Imagining the Middle East. Canada: Black Rose Books. 
Holm, U. (2004). The EU's Security Policy towards the Mediterranean: An (Im) Possible Combination of Export of European Political Values and Anti-Terror Measures? DIIS Working Paper No. 2004/13, Danish Institute for International Affairs, Copenhagen.

Jawad H. (1992). Euro-Arab Dialogue. Reading: Ithaca.

Kadığlu M. (2016). Türk Denizcilik Tarihi. İstanbul: Derleme Yayınevi.

Kant I. (1801). Physische Geographie. Mainz: G. Vollmer.

Kolluoğlu B. \& Toksöz M. (2010). (Eds.) Cities of the Mediterranean: From the Ottomans to the Present Day. New York: I. B. Tauris.

Richards P. (1974). Kant's Geography and Mental Maps, Transactions of the Institute of British Geographers, No. 61( 1-16).

Kumrular Ö. (2009). “The creation of the Image of the Turk in $16^{\text {th }}$ Century Mediterranean”, Jezernik B. (Ed.) Imagining The Turk. (pp. 27-46) Cambridge: Cambridge Scholar Publishing.

Laurence Publicover (2017). Dramatic Geography, Oxford University Press.

Lefebvre H. (1974, 1984). The Production of Space (Trans. Smith D. N). Oxford: Blackwell.

Lesser I.O. (2016). “The Eastern Meditereanean Vortex”. Turkish Policy Quarterly, 15(1). 25-31.

Longworth M. D. (1921), “The Portuguese and Turks in the Indian Ocean in the 16th century”, Journal of the Royal Asiatic Society, (1) 1-28.

Makdisi U. (2002). Ottoman Orientalism, The American Historical Review, 107(3), 768-96

Malmvig H, (2004). Cooperation or Democratisation? The EU'S conflicting Mediterranean security discourses. DIIS Working Paper, No. 2004.

Massey D. (2006). 'The geographical mind' in Balderston, D. (ed) Secondary Geography Handbook. (pp. 4651)Sheffield: Geographical Association.

Neumann I. (1996). Russia and the Idea of the Europe: A Study in Identity and International Relations. London: Routledge.

Neumann I. (1999). The Uses of the Other. Minnesota: University of Minnesota Press

Nielsen N. (2013) "EU border agency keen to expand Mediterranean Sea surveillance" Brussels, 19. Mar 2013, Available from https://euobserver.com/justice/119473 on 30.11.2017

Öner S.G.I. (2013). Turkey's Refugee Regime Stretched to the Limit? Perceptions 18 (3) 191-228.

Publicover L., (2017) Dramatic Geography, Oxford : Oxford University Press.

Ricci G. (2002) Ossessione turca. In una retrovia cristiana dell'Europa moderna., Il Mulino: Biblioteca storica.

Ross E. D. (1921). The Portuguese in India and Arabia between 1507 and 1517”, The Journal of the Royal Asiatic Society of Great Britain and Ireland, (4) 545-562.

E. D. Ross, (1922). The Portuguese in India and Arabia, 1517-38, The Journal of the Royal Asiatic Society of Great Britain and Ireland, (1), 1-18.

Said E. (1979). “Imaginative Geography and Its Representations: Orientalizing the Oriental.” Orientalism.( pp. 49-72) New York: Vintage.

Salem P. E. (1997). Arab Political Currents" in Guazzone L. (ed.) The Middle East in the Global Change. (pp.23-42) London: Macmillan.

Spencer C. (2002). "The EU as a Security Actor in the Mediterranean: Problems and Prospects." The Quarterly Journal 2(2). 135-142.

Tayfur M.F. (2001). EUROMESCO Available from http://www.euromesco.net on 29.11.2017 
Tuathail, G. (1996) Critical Geopolitics: The Politics of Writing Global Space, Minneapolis: University of Minnesota Press

Vaughan V. M. (1994). Othello: A Contextual History. Cambridge: Cambridge UP

Vitkus D. (2003). Turning Turk. English Theater and the Multicultural Mediterranean, USA: Palgrave Macmillan.

Wright J. K. (1947). “Terra Incognita: The Place of Imagination in Geography”, published in Annals of the Association of American Geographers, 37.

Yanık L.K. (2009). Metamorphosis of Metaphors of Vision: 'Bridging' Turkey's Location, Role and Identity. Geopolitics, 14 (3) 531-549.

Zaimeche S. (2002). "Piri Reis: A Genius 16th-Century Ottoman Cartographer and Navigator" Available from www.muslimheritage.com on 20 October 2017. 